\title{
Pembangunan Septic Tank Komunal Sebagai Upaya Pencegahan Penularan Penyakit Di Wilayah Pesisir Desa Bajo Indah
}

\author{
Noviati*, Sitti Marya Ulva \\ Prodi Kesehatan Masyarakat STIKES Mandala Waluya Kendari
}

\begin{abstract}
ABSTRAK
Letak Desa yang berada di daerah pesisir sehingga penduduk tidak memiliki fasilitas sanitasi yang layak. Banyak masyarakat yang menggunakan jamban cemplung yang tidak memiliki septic tank dan dapat mencemari sumber air. Tujuan diadakan kegiatan pengabdian masyarakat ini adalah untuk menambah pengetahuan dan mengubah perilaku warga Desa Bajo Indah tentang pembuangan tinja bukan pada tempat dapat merusak estetika dan dapat menjadi sumber penyakit. Kegiatan yang dilakukan adalah sosialisasi dengan menggunakan metode ceramah, serta pembuatan septic tank komunal sebagai percontohan bagi warga Desa setempat. Hasil yang diperoleh dari kegiatan pengabdian ini adalah warga telah mengetahui pentingnya pembuangan tinja pada tempatnya. Warga juga sangat antusias dalam membuatan 1 unit septic tank komunal sebagai percontohan yang digunakan oleh 3 rumah, dan lokasi pembuatannya dilakukan di Dusun I Desa Bajo Indah. Diharapkan bagi aparat Desa serta pemerintah setempat, agar memberikan alternatif dalam penindaklanjutan pembuatan septic tank komunal untuk mengurangi beban ekonomi warga, serta tiap warga dapat memiliki jamban yang memenuhi syarat kesehatan.
\end{abstract}

Kata kunci: Penularan Penyakit; Septic Tank Komunal; Desa Bajo Indah

\section{Construction of Communal Septic Tank as Efforts to Prevent Disease Transmission in the Coastal Area of Bajo Indah Village}

\begin{abstract}
The location of the village is in a coastal area, making the residents do not have proper sanitation facilities. Many people use slung toilets that do not have a septic tank and can pollute water sources. The purpose of holding this community service activity is to increase knowledge and change the behavior of residents of Bajo Indah Village about disposing of feces not in place that can damage aesthetics and can be a source of disease. The activities carried out were socialization using the lecture method, as well as building a communal septic tank as a model for local villagers. The results obtained from this service activity were that the residents knew the importance of disposing of feces properly. The residents were also very enthusiastic in constructing 1 unit of the communal septic tank as a pilot for 3 houses, and the location for the construction was done in Hamlet I, Bajo Indah Village. It is hoped that the village apparatus and the local government will provide alternatives in the follow-up to the construction of communal septic tanks to reduce the economic burden on the residents, and every resident can have a toilet that meets health requirements.
\end{abstract}

Keywords: Disease Transmission; Communal Septic Tank; Bajo Indah Village

\author{
Penulis Korespondensi : \\ Noviati, Sitti Marya Ulva \\ STIKES Mandala Waluya Kendari \\ E-mail : noviati.novy@gmail.com \\ No. Hp : 085255085235
}




\section{PENDAHULUAN}

Faktor lingkungan mempunyai peranan yang sangat besar dalam proses timbulnya gangguan kesehatan baik secara individu maupun masyarakat umum. Masalah kesehatan lingkungan yang timbul terutama disebabkan oleh lingkungan yang kurang atau tidak memenuhi syarat kesehatan dan belum terpenuhinya kebutuhan sanitasi dasar seperti penyediaan air bersih, pembuangan sampah, sarana pembuangan air limbah dan pembuangan tinja.

Fasilitas sanitasi yang layak seperti jamban sehat merupakan fasilitas sanitasi yang memenuhi syarat kesehatan antara lain dilengkapi dengan leher angsa, tanki septik/Sistem Pengolahan Air Limbah (SPAL), yang digunakan sendiri atau bersama.

Permasalahan yang dihadapi di Desa Bajo Indah Kecamatan Soropia Kabupaten Konawe merupakan wilayah pesisir yang penduduknya berjumlah 682 orang. Letak Desa yang berada di daerah pesisir sehingga penduduk tidak memiliki fasilitas sanitasi yang layak. Banyak masyarakat yang BAB menggunakan jamban cemplung yang tidak memiliki septik tank dan dapat mencemari sumber air.

Apabila fenomena masyarakat yang BAB pada tempat yang tidak memenuhi syarat terus terjadi sehingga wilayah tersebut terancam munculnya beberapa penyakit menular yang berbasis lingkungan diantaranya penyakit cacingan, kolera (muntaber), diare, tipus, disentri, paratypus, polio, hepatitis B dan masih banyak penyakit lainnya.

Selain itu dapat menimbulkan pencemaran lingkungan pada sumber air dan bau busuk serta estetika. Semakin besar persentase yang $\mathrm{BAB}$ sembarangan maka ancaman penyakit itu semakin tinggi intensitasnya. Oleh karenanya diperlukan jamban yang memenuhi syarat tentunya dengan pengadaan septic tank yang memenuhi syarat sehingga tinja masyarakat tidak menjadi mencemari air. Septic tank komunal menjadi salah satu alternatif untuk memenuhi kebutuhan masyarakat Desa Bajo Indah yang sebagaian besar mata pencahariannya adalah nelayan.

Permasalahan yang ada di Desa Bajo Indah adalah pemahaman dan kesadaran masyarakat masih rendah tentang jamban sehat dan pengadaan septic tank; dan belum ada masyarakat yang membuat septic tank komunal sebagai percontohan, untuk memenuhi syarat jamban sehat.

\section{METODE}

Kegiatan ini dilaksanakan dalam 2 (dua) tahap, yaitu tahap pertama dilakukan penyuluhan atau sosialisasi kepada masyarakat setempat dengan tema: "Ciptakan Lingkungan Bersih dan Sehat melalui Pembangunan Septic Tank Komunal sebagai Upaya Pencegahan Penularan Penyakit di Wilayah Pesisir", kemudian dilanjutkan dengan sesi tanya jawab.

Tahap kedua adalah pembuatan septic tank komunal sebagai percontohan, untuk memenuhi syarat jamban sehat.

\section{HASIL DAN PEMBAHASAN}

Kegiatan penyuluhan atau sosialisasi dilakukan pada tanggal 15 Februari 2020, pukul 16.30 wita, bertempat di Balai Pertemuan Desa Bajo Indah, dan dihadiri oleh 23 orang warga Desa Bajo Indah yang terdiri dari salah seorang petugas puskesmas, kepala dusun, serta warga dusun 1,2 , dan 3 . Peserta penyuluhan sangat antusias dalam mengikuti kegiatan ini dan 
kegiatan berjalan lancar, seperti terlihat pada gambar 1 dibawah ini.

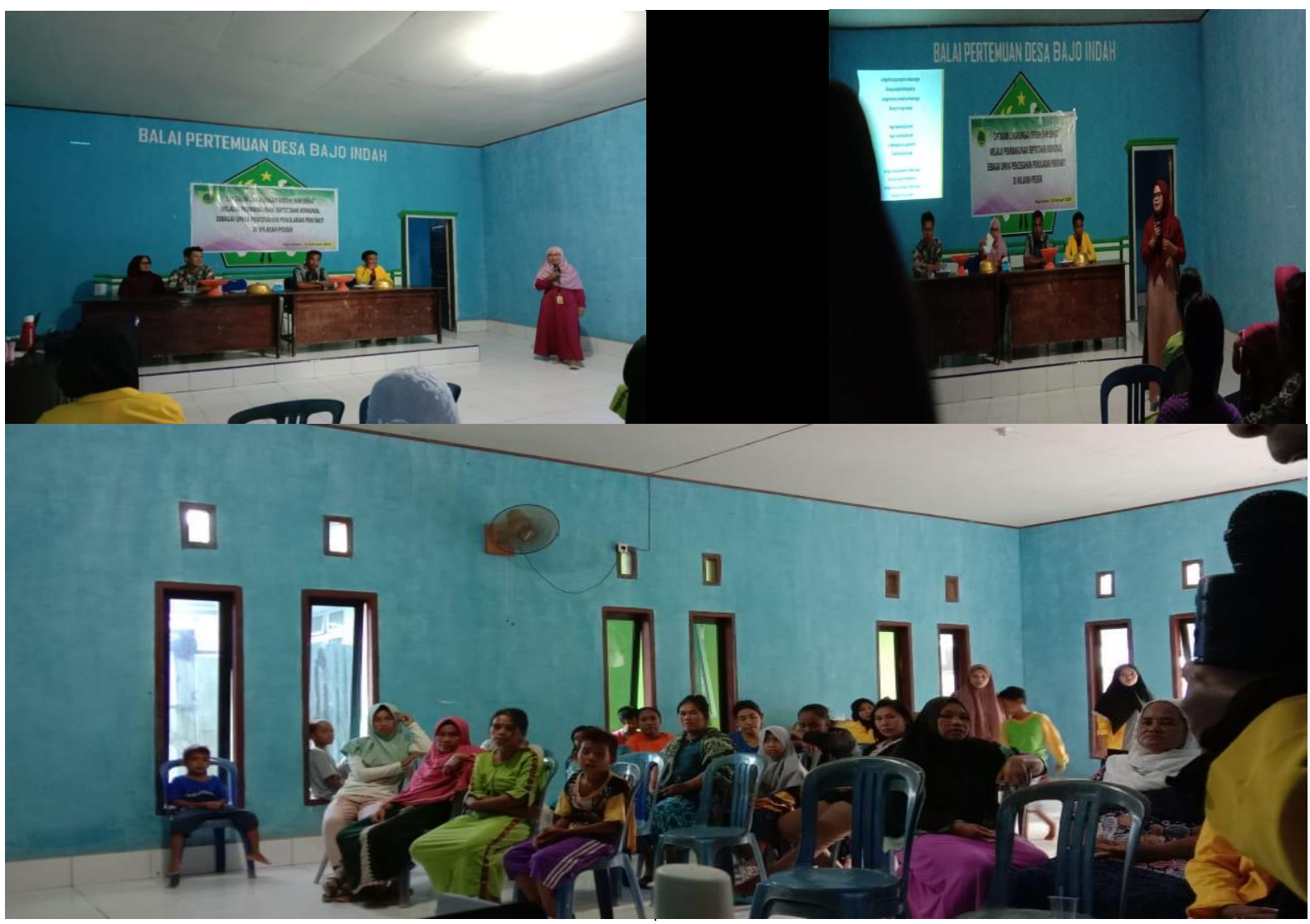

Gambar 1. Kegiatan Penyuluhan

Kegiatan pengabdian masyarakat ini dilanjutkan dengan pembuatan septic tank komunal sebagai percontohan. Berdasarkan kesepakatan warga Desa Bajo Indah, maka pembuatan septic tank komunal dilakukan di Dusun I Desa Bajo Indah.

Pembuatan septic tank komunal yaitu, pertama-tama dilakukan penentuan lokasi; kedua, menyiapkan bahan; kemudian proses penggalian septic tank hingga mencapai kedalaman kurang lebih $30 \mathrm{~cm}$, tinggi cincin $50 \mathrm{~cm}$, luas diameternya $80 \mathrm{~cm}$. Lubang yang telah ada kemudian dimasukan cincin yang sudah disesuaikan dengan besarnya lubang galian. Setelah itu, dilakukan penutupan lubang menggunakan penutup cincin yang sudah disediakan, dan terakhir dilakukan proses pemasangan pipa dari kloset ke lubang septic tank.

Septic tank yang di buat berjumlah 1 unit yang akan digunakan oleh tiga rumah, seperti terlihat pada gambar 2. Peran masyarakat cukup tinggi, dimana dalam pembuatan septic tank ini masyarakat Desa Bajo Indah yang turun langsung dalam proses pembuatannya. 


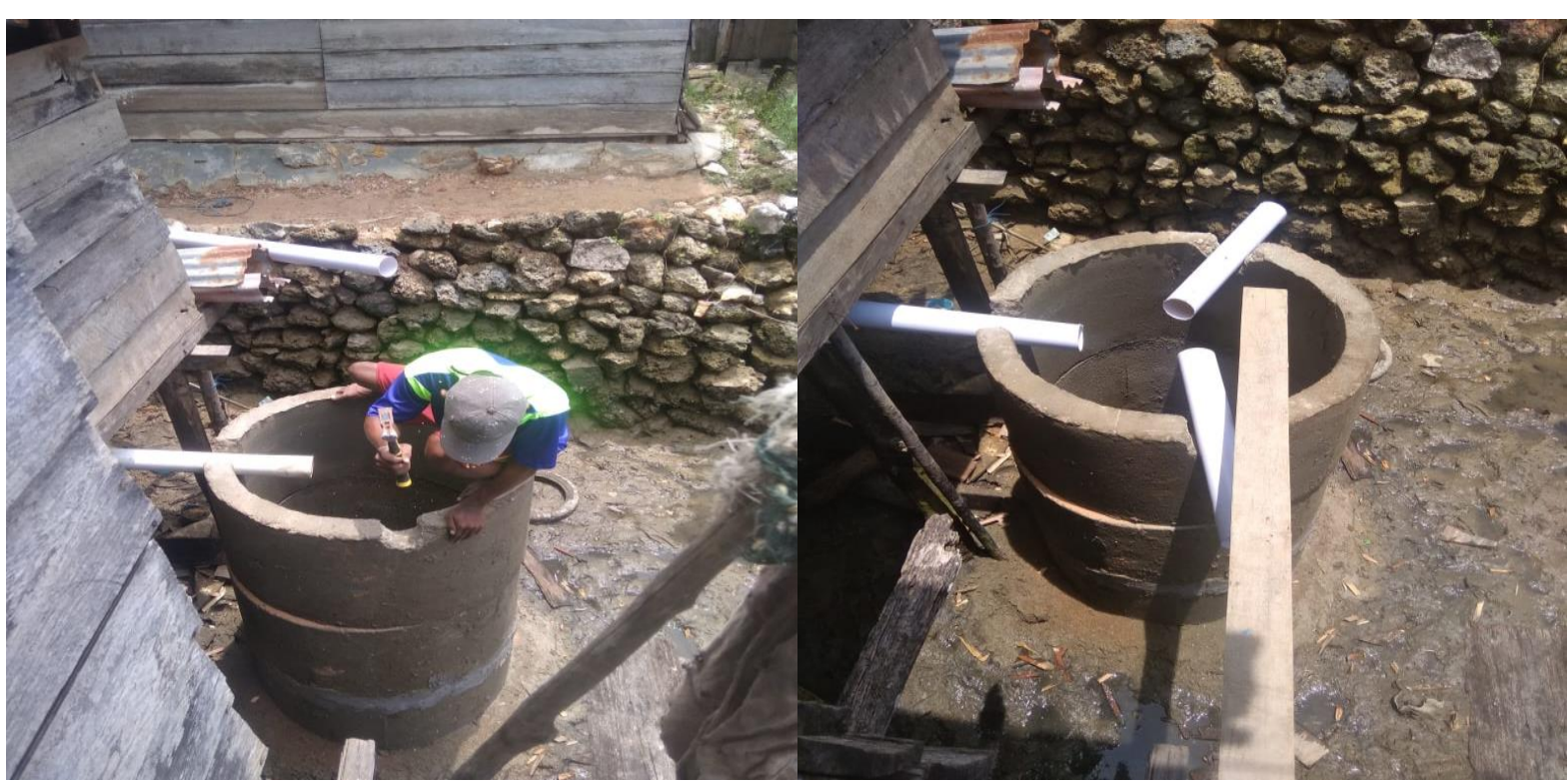

Gambar 2. Pembuatan Septic Tank Komunal

Adanya bangunan tangki septik (septic tank) dalam skala komunal sangat efektif untuk menurunkan tingkat pencemaran dan melindungi ekosistem perairan. Perencanaan tangki septik komunal sebagai wujud dari intalasi pengolahan air limbah dalam skala kecil merupakan elemen yang sangat esensial untuk memperlancar sanitasi masyarakat dalam mempertahankan stabilitas ekosistem lingkungan.

Warga Desa Bajo Indah masih ada yang memiliki pemahaman kurang tentang pentingnya fasilitas jamban sehat, dan dampak yang akan ditimbulkan akibat tidak tersedianya jamban yang memenuhi syarat kesehatan pada rumah tangga.

Kurangnya pengetahuan warga Desa Bajo Indah tentang pentingnya memiliki jamban yang memenuhi syarat kesehatan, sehingga warga telah terbiasa menggunakan jamban yang tidak memenuhi syarat seperti diantaranya jamban yang tidak mempunyai septic tank sehingga warga lebih memilih untuk buang air besar di tempat-tempat terbuka, dan lebih memilih membuang air besar menggunakan jamban cemplung. Faktor pendorong lainnya yang membuat warga harus menggunakan jamban cemplung adalah faktor ekonomi yang tidak mencukupi untuk pembuatan jamban yang memenuhi syarat di rumah mereka.

Setelah dilakukan pengabdian masyarakat, berupa pemberian penyuluhan atau sosialisasi terkait septic tank serta pembangunan septic tank komunal sebagai percontohan bagi warga Desa Bajo Indah, maka dapat diketahui bahwa warga telah memperoleh pemahaman, sehingga dapat meningkatkan kesadaran warga tentang jamban sehat.

\section{KESIMPULAN}

Berdasarkan hasil dan pembahasan yang diperoleh, maka dapat disimpulkan bahwa Setelah diberikan penyuluhan ataupun sosialisasi dengan tema "Ciptakan Lingkungan Bersih dan Sehat melalui Pembangunan Septic Tank Komunal sebagai Upaya Pencegahan Penularan Penyakit di Wilayah Pesisir", maka warga Desa Bajo Indah telah 
memperoleh pemahaman dan

kesadaran tentang jamban sehat serta pentingnya membuat septic tank.

\section{UCAPAN TERIMA KASIH}

Dalam menyelesaikan kegiatan pengabdian masyarakat ini, kami telah dibantu dari berbagai pihak, untuk itu kami mengucapkan terima kasih kepada

1. Ketua Badan Pengurus Yayasan dan Rektor Universitas Mandala Waluya, yang telah memberikan bantuan dana untuk pelaksanaan kegiatan ini;

2. Ketua LPPM, dan Dekan Fakultas, serta Ketua Program Studi Kesehatan Masyarakat Universitas Mandala Waluya, yang telah memberikan izin pelaksanaan kegiatan;

3. Kepala Desa, Aparat Desa, dan warga Desa setempat yang telah berkenan menerima kami untuk melakukan kegiatan pengabdian masyarakat di Desa Bajo Indah; dan
4. Adik-adik mahasiswa program Studi Kesehatan Masyarakat yang terlibat dalam kegiatan ini.

\section{DAFTAR PUSTAKA}

Anonim. (2016).

https://bontang.prokal.co/rea d/news/8013-bangun-septictank-komunal-cegahpencemaran-laut-dari-limbahrumah-tangga.

Asep Sapei, dkk. (2011). Desain instalasi pengolah limbah WC komunal Masyarakat pinggir sungai Desa Lingkar Kampus. Jurnal Ilmu Pertanian Indonesia, Vol. 16 No.2. hlm. 91-99

Laporan PBL I 2019. Desa Bajo Indah Kecamatan Soropia.

Sudarmaji, Hamdi. (2013). Tangki Septik dan Peresapannya Sebagai Sistem Pembuangan Air Kotor di Permukiman Rumah Tinggal Keluarga.Teknik Sipil.Vol 9(2):134142. 